\title{
Probing $\mathrm{Pb}^{2+}$ cation via the iridium based phosphorescent dye
}

\author{
Mei-Lin Ho ${ }^{\text {a }}$, Yi-Ming Cheng ${ }^{\text {a }}$, Lai-Chin $\mathrm{Wu}^{\mathrm{a}}$, Pi-Tai Chou ${ }^{\mathrm{a}, *}$, Gene-Hsiang Lee ${ }^{\mathrm{a}, *}$, \\ Fang-Chi Hsu ${ }^{b}$, Yun Chi ${ }^{\text {,** }}$ \\ a Department of Chemistry, National Taiwan University, Taipei 106, Taiwan \\ b Department of Chemistry, National Tsing Hua University, Hsinchu 300, Taiwan
}

Received 11 April 2007; accepted 21 June 2007

Available online 6 July 2007

\begin{abstract}
We demonstrate the concept of $\mathrm{Pb}^{2+}$ cation sensing using the emissive $\mathrm{Ir}(\mathrm{III})$ complex (1) based on the associated decrease of roomtemperature phosphorescence upon forming the $1: 1$ adduct $1-\mathrm{Pb}^{2+}$. Complex 1 bears two cyclometalated $N$-phenyl pyrazoles with pyrazoles residing at the mutual trans dispositions as well as one 3,5-di(pyridyl) pyrazolate chelate. X-ray structural analyses on the adduct $1-\mathrm{Pb}^{2+}$ confirm the key function of 3,5-di(pyridyl) pyrazolate as it forms chelate interaction with the metal analytes, while quenching of phosphorescent emission is probably due to the $\mathrm{Pb}^{2+}$ induced perturbation, which increases the intersystem crossing to another lowerlying triplet state for the host chromophore via an enhanced spin-orbit coupling.
\end{abstract}

(C) 2007 Elsevier Ltd. All rights reserved.

Keywords: Iridium; Phosphorescence; Pyridyl pyrazolate; $\mathrm{Pb}^{2+}$; Cation sensor

\section{Introduction}

Owing to their toxicity to human life, the identification of heavy metal ions in the environment remained to be an important issue. Among these, lead should be one of the most serious environmental concerns and health threats. It has been known that the toxicity of lead affects the kidneys, reproductive system, and nervous systems [1]. The FDA limit for lead in drinking water is $0.015 \mathrm{mg} / \mathrm{L}\left(7.2 \times 10^{-8} \mathrm{M}\right)[2]$. Development of optical sensors for $\mathrm{Pb}^{2+}$ would thus help to clarify the $\mathrm{Pb}^{2+}$ ions in vivo as well as to monitor its concentration in the contaminated sources [3]. Recently, Chen et al. [1] used a coumarine derivative bearing an azacrown binding site as a new ratiometric fluorescent sensor for $\mathrm{Pb}^{2+}$ in acetonitrile, for which the specificity is attributed to the carbonyl lariat formation. Godwin et al. also reported a new ratiometric

\footnotetext{
* Corresponding authors. Tel.: +886 3 5712956; fax: +886 35720864 (Y. Chi)

E-mail addresses: chop@ntu.edu.tw (P.-T. Chou), ychi@mx.nthu. edu.tw (Y. Chi).
}

fluorescent sensor for $\mathrm{Pb}^{2+}$ based on the dansyl-tetrapeptide framework [4]. In another approach, Czarnik et al. synthesized 9-anthracene derivatives bearing $N$-methylthiohydroxamate ligand, which is capable of quenching fluorescence in the uncomplexed form with certain selectivity [5]. Yoon et al. reported a new fluorescent sensor for $\mathrm{Pb}^{2+}$ based on rhodamine $\mathrm{B}$, which displayed a good selectivity for $\mathrm{Pb}^{2+}$ in acetonitrile solution compared with other metal ions examined [6]. Although much work has been devoted in developing various fluorescent chemosensors for metal ions [4-6], there have been relatively few reports on the respective phosphorescence chemosensors $[7,8]$. Recently, extension was made to systems with third-row transition-metal complexes, among which the majority of these sensors comprised of a highly efficient phosphorescent entity, together with at least one crown ether substituent that allowed selective binding to the designated metal cations [9].

Typical signaling involves the switching of the non-emissive intra-ligand ( $\left.{ }^{3} \mathrm{IL}\right) \pi \pi^{*}$ and metal-to-ligand charge transfer $\left({ }^{3} \mathrm{MLCT}\right)$ states $[8,10]$ such that positive luminescent response versus concentrations of metal cations, e.g. 
$\mathrm{Ca}^{2+}, \mathrm{Hg}^{2+}$ or $\mathrm{Pb}^{2+}$, can be obtained. Moreover, it may allow the design of "light-controlled ion switches", for which the cation ejection from, e.g. the crown ether can be triggered by the effective reduction of electron donation at the receptor on excitation of the nearby chromophore [11]. As many of heavy metals are known as fluorescence quenchers via enhanced spin-orbit coupling [12], it is thus intriguing and of both fundamental and application importance to examine the interaction between environmental hazard metals such as $\mathrm{Pb}^{2+}$ (or $\mathrm{Hg}^{2+}$ ) and heavy metal complexes that mainly exhibit room-temperature phosphorescence in solution due to the strong spin-orbit coupling effect.

Aiming at this goal, we present a novel phosphorescence sensor, in which an 3,5-di(pyridyl)pyrazole ( $\left.\mathrm{py}_{2} \mathrm{pz}\right)$ moiety is attached to the heteroleptic Ir(III) complex (1). This design provides three inherent advantages [13]. First, the Ir(III) metal atom forms highly stable, octahedral coordinated structure and inherits strong phosphorescent emission due to the heavy atom effect induced by the $\operatorname{Ir}(\mathrm{III})$ metal center. Moreover, the ancillary cyclometalated $N$ phenyl pyrazole ligands, for which their $\pi \pi^{*}$ energy levels are far greater than those of the respective MLCT and other ligand-centered $\pi \pi^{*}$ excited states [14], enable both the HOMO and LUMO to reside predominantly on the ancillary $\mathrm{py}_{2} \mathrm{pz}$ segment. Thirdly, the $\mathrm{py}_{2} \mathrm{pz}$ fragment is attached to the Ir(III) metal center and then forming a neutral metal complex. Such a charge-neutral characteristic is similar to that of the $\operatorname{Re}(\mathrm{I})$ and $\mathrm{Pt}(\mathrm{II})$ based sensor complexes, but is in sharp contrast to most of the Ru(II) based polypyridyl sensors [15], for which the net cationic charge on the overall metal complex is expected to reside, in part, at the ligand site, giving a much reduced sensitivity in recognizing metal cations [16]. Finally, the nitrogen atoms of the $\mathrm{py}_{2} \mathrm{pz}$ moiety would act as the effective donor site, allowing the direct recognition of the incoming cationic analytes. In other words, the $\mathrm{py}_{2} \mathrm{pz}$ segment acts as crab chela and can potentially be used for distinguishing metal ions, simplifying the design strategy (see Scheme 1).

\section{Experimental}

\subsection{General information and materials}

Elemental analyses and Mass spectra (operating in FAB mode) were carried out at the NSC Regional Instrument Centre at National Chiao Tung University, Taiwan. ${ }^{1} \mathrm{H}$

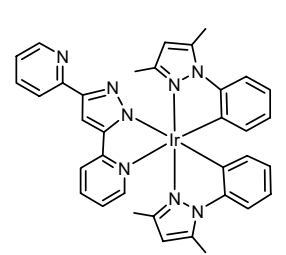

(1)

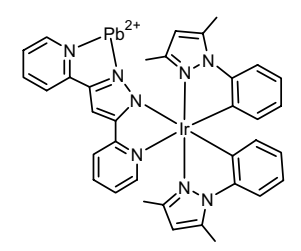

$\left(1-\mathrm{Pb}^{2+}\right)$

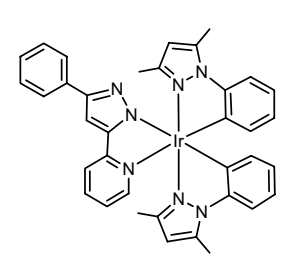

(2)
Scheme 1. and ${ }^{13} \mathrm{C}$ NMR spectra were recorded on a Varian Mercury 400 instrument; chemical shifts are quoted with respect to internal standard $\mathrm{Me}_{4} \mathrm{Si}$. All synthetic manipulations were performed under $\mathrm{N}_{2}$ atmosphere, while solvents were used as received. Synthesis of 3,5-di(2-pyridyl) pyrazole $\left(\mathrm{py}_{2} \mathrm{pz}\right) \mathrm{H}, 3-$ phenyl-5-(2-pyridyl) pyrazole (ppypz)H and 1-phenyl-3,5-dimethyl pyrazole (pdpz)H follows the procedures documented in the literature [17]. Treatment of (pdpz)H with $\mathrm{IrCl}_{3} \cdot n \mathrm{H}_{2} \mathrm{O}$ in refluxing methoxyethanol afforded the chloride bridged dimer $\left[(\mathrm{pdpz})_{2} \mathrm{IrCl}\right]_{2}$ in $75 \%$ yield [14]; it was then used for subsequent reactions without further purification.

\subsection{Preparation of $\left[(p d p z)_{2} \operatorname{Ir}\left(p y_{2} p z\right)\right](1)$}

A mixture of $\left[(\mathrm{pdpz})_{2} \mathrm{IrCl}\right]_{2}(150 \mathrm{mg}, 0.13 \mathrm{mmol}), 3,5-$ di(2-pyridyl) pyrazole ( $\mathrm{py}_{2} \mathrm{pzH}, 64 \mathrm{mg}, 0.29 \mathrm{mmol}$ ) and $\mathrm{Na}_{2} \mathrm{CO}_{3} \quad(93 \mathrm{mg}, \quad 0.88 \mathrm{mmol})$ in 2-methoxyethanol $(25 \mathrm{~mL})$ was heated to reflux for 6 hours. Excess of water was added after cooling the solution to room temperature. The precipitate was collected by filtration and subjected to silica gel column chromatography, eluting with a mixture of ethyl acetate and methanol (9:1). Pale yellow crystals of $\left[(\mathrm{pdpz})_{2} \operatorname{Ir}\left(\mathrm{py}_{2} \mathrm{pz}\right)\right]$ (1) were obtained from repeated recrystallization using a mixture of THF and pentane at room temperature (49 $\mathrm{mg}, 0.065 \mathrm{mmol}, 50 \%$ ).

Spectral data of 1: MS (FAB, $\left.{ }^{193} \mathrm{Ir}\right): \mathrm{m} / z 756\left(\mathrm{M}^{+}\right) .{ }^{1} \mathrm{H}$ NMR $\left(400 \mathrm{MHz}\right.$, DMSO- $\left.d_{6}, 298 \mathrm{~K}\right): \delta 8.43(\mathrm{~d}, 1 \mathrm{H}$, $\left.J_{\mathrm{HH}}=4.8 \mathrm{~Hz}\right), 7.99\left(\mathrm{~d}, 1 \mathrm{H}, J_{\mathrm{HH}}=7.6 \mathrm{~Hz}\right), 7.84(\mathrm{t}, 1 \mathrm{H}$, $\left.J_{\mathrm{HH}}=7.8 \mathrm{~Hz}\right), 7.63\left(\mathrm{t}, 1 \mathrm{H}, J_{\mathrm{HH}}=7.6 \mathrm{~Hz}\right), 7.60(\mathrm{t}, 1 \mathrm{H}$, $\left.J_{\mathrm{HH}}=8.0 \mathrm{~Hz}\right) 7.53\left(\mathrm{~d}, 1 \mathrm{H}, J_{\mathrm{HH}}=5.6 \mathrm{~Hz}\right), 7.47(\mathrm{~d}, 1 \mathrm{H}$, $\left.J_{\mathrm{HH}}=8.0 \mathrm{~Hz}\right), 7.42\left(\mathrm{~d}, 1 \mathrm{H}, J_{\mathrm{HH}}=8.4 \mathrm{~Hz}\right), 7.39(\mathrm{~s}, 1 \mathrm{H})$, $7.07\left(\mathrm{t}, 2 \mathrm{H}, J_{\mathrm{HH}}=6.4 \mathrm{~Hz}\right), 6.95\left(\mathrm{t}, 1 \mathrm{H}, J_{\mathrm{HH}}=8.0 \mathrm{~Hz}\right)$, $6.86\left(\mathrm{t}, 1 \mathrm{H}, J_{\mathrm{HH}}=8.0 \mathrm{~Hz}\right), 6.75\left(\mathrm{t}, 1 \mathrm{H}, J_{\mathrm{HH}}=7.6 \mathrm{~Hz}\right)$, $6.65\left(\mathrm{t}, 1 \mathrm{H}, J_{\mathrm{HH}}=7.6 \mathrm{~Hz}\right), 6.28\left(\mathrm{~d}, 1 \mathrm{H}, J_{\mathrm{HH}}=7.2 \mathrm{~Hz}\right)$, $6.23\left(\mathrm{~d}, 1 \mathrm{H}, J_{\mathrm{HH}}=8.0 \mathrm{~Hz}\right), 6.20(\mathrm{~s}, 1 \mathrm{H}), 6.16(\mathrm{~s}, 1 \mathrm{H})$, 2.75 (s, 3H, Me), 2.72 (s, 3H, Me), 1.50 (s, 3H, Me), 1.47 (s, 3H, Me). Anal. Calc. for $\mathrm{C}_{35} \mathrm{H}_{31} \mathrm{IrN}_{8}: \mathrm{C}, 55.61 ; \mathrm{N}$, 14.82; H, 4.13. Found: C, 55.37; N, 14.46; H, 4.20\%.

\subsection{Preparation of $\left[(p d p z){ }_{2} \operatorname{Ir}(\right.$ ppypz $\left.)\right]$ (2)}

A mixture of $\left[(\mathrm{pdpz})_{2} \mathrm{IrCl}\right]_{2}(200 \mathrm{mg}, 0.17 \mathrm{mmol}), 3$-phenyl-5-(2-pyridyl) pyrazole (ppypzH, $85 \mathrm{mg}, 0.38 \mathrm{mmol}$ ) and $\mathrm{Na}_{2} \mathrm{CO}_{3} \quad(214 \mathrm{mg}, \quad 0.21 \mathrm{mmol})$ in 2-methoxyethanol $(25 \mathrm{~mL})$ was heated to reflux for $6 \mathrm{~h}$. Excess of water was added after cooling the solution to room temperature. The precipitate was collected by filtration and subjected to silica gel column chromatography, eluting with a mixture of ethyl acetate and methanol (9:1). Pale yellow crystals of $\left[(\mathrm{pdpz})_{2} \operatorname{Ir}(\mathrm{ppypz})\right]$ (2) were obtained from repeated recrystallization using a mixture of THF and pentane at room temperature (68 $\mathrm{mg}, 0.009 \mathrm{mmol}, 53 \%$ ).

Spectral data of 2: MS (FAB, $\left.{ }^{193} \mathrm{Ir}\right): m / z 755\left(\mathrm{M}^{+}\right) .{ }^{1} \mathrm{H}$ NMR $\left(400 \mathrm{MHz}\right.$, DMSO- $\left._{6}, 298 \mathrm{~K}\right): \delta 7.91(\mathrm{~d}, 1 \mathrm{H}$, $\left.J_{\mathrm{HH}}=7.6 \mathrm{~Hz}\right), 7.82\left(\mathrm{t}, 1 \mathrm{H}, J_{\mathrm{HH}}=7.2 \mathrm{~Hz}\right), 7.59(\mathrm{~d}, 1 \mathrm{H}$, $\left.J_{\mathrm{HH}}=7.2 \mathrm{~Hz}\right), 7.52\left(\mathrm{~d}, 1 \mathrm{H}, J_{\mathrm{HH}}=6.2 \mathrm{~Hz}\right), 7.46(\mathrm{~d}, 1 \mathrm{H}$, 
$\left.J_{\mathrm{HH}}=8.0 \mathrm{~Hz}\right), 7.40\left(\mathrm{~d}, 1 \mathrm{H}, J_{\mathrm{HH}}=8.0 \mathrm{~Hz}\right), 7.24(\mathrm{t}, 2 \mathrm{H}$, $\left.J_{\mathrm{HH}}=8.0 \mathrm{~Hz}\right), 7.19(\mathrm{~s}, 1 \mathrm{H}), 7.08\left(\mathrm{t}, 1 \mathrm{H}, J_{\mathrm{HH}}=7.2 \mathrm{~Hz}\right)$, $7.04\left(\mathrm{t}, 1 \mathrm{H}, J_{\mathrm{HH}}=6.2 \mathrm{~Hz}\right), 6.93\left(\mathrm{t}, 2 \mathrm{H}, J_{\mathrm{HH}}=7.6 \mathrm{~Hz}\right)$, $6.84\left(\mathrm{t}, 1 \mathrm{H}, J_{\mathrm{HH}}=8.0 \mathrm{~Hz}\right), 6.74\left(\mathrm{t}, 1 \mathrm{H}, J_{\mathrm{HH}}=7.6 \mathrm{~Hz}\right)$, $6.63\left(\mathrm{t}, 1 \mathrm{H}, J_{\mathrm{HH}}=7.6 \mathrm{~Hz}\right), 6.27\left(\mathrm{~d}, 1 \mathrm{H}, J_{\mathrm{HH}}=7.2 \mathrm{~Hz}\right)$, $6.22\left(\mathrm{~d}, 1 \mathrm{H}, J_{\mathrm{HH}}=7.2 \mathrm{~Hz}\right), 6.19(\mathrm{~s}, 1 \mathrm{H}), 6.15(\mathrm{~s}, 1 \mathrm{H})$, 2.77 (s, 3H, Me), 2.74 (s, 3H, Me), 1.52 (s, 3H, Me), 1.50 (s, 3H, Me). Anal. Calc. for $\mathrm{C}_{36} \mathrm{H}_{32} \mathrm{IrN}_{7}: \mathrm{C}, 57.28 ; \mathrm{N}$, 12.99; H, 4.27. Found: C, 57.14; N, 13.01; H, 4.28\%.

\subsection{Preparation of $\left[(\mathrm{pdpz})_{2} \mathrm{Ir}\left(\mathrm{py} y_{2} \mathrm{pz}\right) \mathrm{Pb}\left(\mathrm{ClO}_{4}\right)_{2}\right]-$ $\left(1-P b^{2+}\right)$}

$\mathrm{Pb}\left(\mathrm{ClO}_{4}\right)_{2} \cdot \mathrm{H}_{2} \mathrm{O}(18.7 \mathrm{mg}, 0.046 \mathrm{mmol})$ was dissolved in $6 \mathrm{~mL}$ acetonitrile and then added into a glass tube with solid sample of 1 (17.4 mg, $0.023 \mathrm{mmol})$. The light greenyellow crystal suitable for single crystal X-ray diffraction was grown by ether diffusion for several days.

\subsection{X-ray diffraction study}

Single crystal X-ray diffraction data were measured on a Bruker SMART Apex CCD diffractometer using (Mo K $\alpha$ ) radiation $(\lambda=0.71073 \AA)$. The data collection was executed using the SMART program. Cell refinement and data reduction were performed with the SAINT program. The structure was determined using the SHELXTL/PC program and refined using full-matrix least squares.

Crystal data for $1-\mathrm{Pb}^{2+}: \mathrm{C}_{35} \mathrm{H}_{31} \mathrm{Cl}_{2} \mathrm{IrN}_{8} \mathrm{O}_{8} \mathrm{~Pb}, \mathrm{M}=$ 1161.97, monoclinic, space group $P 2_{1} / n, T=150 \mathrm{~K}, a=$ 19.0572(12), $b=9.9577(6), c=19.2354(12) \AA, \beta=91.354$ $(2)^{\circ}, U=3649.2(4) \AA^{3}, Z=4, \mu($ Mo $\mathrm{K} \alpha)=8.462 \mathrm{~mm}^{-1}$, 24109 reflections collected, 8360 unique $\left(R_{\text {int }}=0.0604\right)$, final $R_{1}[I>2 \sigma(I)]=0.0391, w R_{2}($ all data $)=0.0898$.

\section{6. $U V-V i s$ and phosphorescence titration of compounds $\mathbf{1}$ with $\mathrm{Pb}^{2+}$ ions}

The stock solution of compound $1\left(2 \times 10^{-5} \mathrm{M}\right)$ was prepared by using spectroscopic grade $\mathrm{CH}_{3} \mathrm{CN}$. The solution of $\mathrm{Pb}^{2+}$ ions $\left(1 \times 10^{-3} \mathrm{M}\right)$ was prepared by using $\mathrm{Pb}\left(\mathrm{ClO}_{4}\right)_{2}$ hydrate dissolved in $\mathrm{CH}_{3} \mathrm{CN}$. The solutions of 1 in the titration range exhibited a linear dependence of absorption and emission. The absorption and emission spectrum of $\mathbf{1}$ (3.2 $\mathrm{mL}$ of $2 \times 10^{-5} \mathrm{M}$ stock solution) in a quartz cell $(1 \mathrm{~cm}$ width) were recorded at $298 \mathrm{~K}$. The absorption titration of 1 with $\mathrm{Ca}^{2+}$ and $\mathrm{Hg}^{2+}$ ions were carried out by a procedure similar to that for $\mathrm{Pb}^{2+}$ ion.

\subsection{Measurements}

Steady-state absorption and emission spectra were recorded by a Hitachi (U-3310) spectrophotometer and an Edinburgh (FS920) fluorimeter, respectively. The association constant $K_{\mathrm{a}}$ of 1:1 1/guest complex formation calculated by the UV-Vis absorption method is obtained by the following equation [18]:
$\frac{A_{0}}{A_{0}-A}=\left(\frac{\varepsilon_{\mathrm{M}}}{\varepsilon_{\mathrm{M}}-\varepsilon_{\mathrm{p}}}\right)\left[\frac{1}{K_{\mathrm{a}} C_{\mathrm{g}}}+1\right]$

where $C_{\mathrm{g}}$ is the added guest (e.g. $\mathrm{Pb}^{2+}$ ) concentration. $A_{0}$ $\left(\varepsilon_{\mathrm{M}}\right)$ and $A\left(\varepsilon_{\mathrm{p}}\right)$ denote the absorbance (molar extinction coefficient) of free $\mathbf{1}$, and solution after adding, e.g. $\mathrm{Pb}^{2+}$, respectively, at a selective wavelength. Eq. (1) can be further extended to the emission titration experiment expressed as

$\frac{F_{0}}{F_{0}-F}=\frac{\Phi_{\mathrm{M}} \varepsilon_{\mathrm{M}}}{\left(\Phi_{\mathrm{M}} \varepsilon_{\mathrm{M}}-\Phi_{\mathrm{p}} \varepsilon_{\mathrm{p}}\right)}\left(\frac{1}{K_{\mathrm{a}} C_{\mathrm{g}}}+1\right)$

where $F_{0}\left(\Phi_{\mathrm{M}}\right)$ and $F\left(\Phi_{\mathrm{p}}\right)$ denote the photoluminescence (quantum yield) of free $\mathbf{1}$, and that of solution after adding $\mathrm{Pb}^{2+}$, respectively, at a selective wavelength. Details of nanosecond lifetime measurements have been described in previous publication [19].

\section{Results and discussions}

As shown in Fig. 1, ion-free $\mathbf{1}$ in $\mathrm{CH}_{3} \mathrm{CN}$ exhibits a weak $426 \mathrm{~nm}\left(\varepsilon=235 \mathrm{M}^{-1} \mathrm{~cm}^{-1}\right)$ absorption band, which is assigned to the spin-forbidden ${ }^{3} \pi \pi^{*}\left({ }^{3}\right.$ ILCT) transition perhaps mixed with a small amount of the ${ }^{3}$ MLCT transition to the $\mathrm{py}_{2} \mathrm{pz}$ ligands. The absorption band around $300 \mathrm{~nm}$ ( $\varepsilon \sim 10^{4} \mathrm{M}^{-1} \mathrm{~cm}^{-1}$ ) is attributed to the ${ }^{1} \pi \pi^{*}$ transition, while transitions associated with ${ }^{1}$ MLCT are relatively weak and thus are possibly hidden underneath the ${ }^{1} \pi \pi^{*}$ bands. In degassed or $\mathrm{N}_{2}$ purged $\mathrm{CH}_{3} \mathrm{CN}, 1$ exhibits a $485 \mathrm{~nm}$ emission with moderate intensity $(\Phi \sim 0.04$, $\tau \sim 70 \mathrm{~ns})$. Upon aeration, the emission yield is reduced to 0.01 ( $\tau \sim 21 \mathrm{~ns})$. The strong $\mathrm{O}_{2}$ quenching and a calculated long radiative lifetime of $\sim 2.6 \mu$ s lead us to conclude that the emission unambiguously originates from phosphorescnece.

The absorption and luminescence spectra recorded for $\mathbf{1}$ upon titrated with $\mathrm{Pb}^{2+}$ are also depicted in Fig. 1. Note that the titration was performed in the aerated solution.

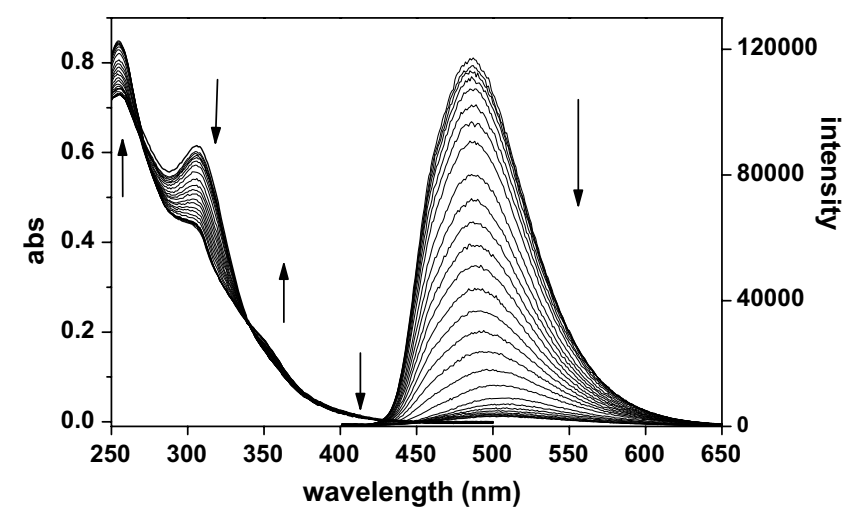

Fig. 1. The absorption and emission spectra of $1\left(2.0 \times 10^{-5}\right.$ in aerated $\mathrm{CH}_{3} \mathrm{CN}$ ) upon addition of increasing amounts of $\mathrm{Pb}^{2+}$ at (a) 0 , (b) 0.07 , (c) 0.13 , (d) 0.20 , (e) 0.33 , (f) 0.47 , (g) 0.60 , (h) 0.80 , (i) 1.07 , (j) 1.27 , (k) 1.43, (1) 1.60, (m) 1.77, (n) 1.93, (o) 2.10, (p) 2.27, (q) 2.43, (r) 2.60, (s) 2.77, (t) 2.93, (u) 3.10, (v) 3.27, (w) 3.43, (x) 3.60, (y) 3.77, (z) 3.93, (aa) 4.10, (ab) $4.27 \mu \mathrm{M}$ of $1, \lambda_{\mathrm{ex}}: 339 \mathrm{~nm}$. 
Evidently, the addition of $\mathrm{Pb}^{2+}$ caused a significant change of the absorption spectral profile with an isosbestic point appearing at $\sim 340 \mathrm{~nm}$, indicating the existence of ground-state equilibrium between two species, namely the free and $\mathrm{Pb}^{2+}$ linked $1-\mathrm{Pb}^{2+}$ complexes. Concomitantly, upon excitation at the isosbestic point, the $485 \mathrm{~nm}$ phosphorescence was gradually red shifted toward $505 \mathrm{~nm}$, accompanied by the drastic decrease of the emission intensity. Taking the emission peak intensity of $\mathbf{1}$ and $\mathbf{1}-\mathrm{Pb}^{2+}$ to be $\mathrm{F}_{0}$ and $\mathrm{F}$, respectively, a straight line plot of $F_{0} /\left(F_{0}-F\right)$ versus $1 /\left[\mathrm{Pb}^{2+}\right]$ at, e.g. $485 \mathrm{~nm}$ is depicted in Fig. 2, supporting the 1:1 complexation ratio. Additional evidence was provided by the Job's plot analysis [20], in which decreases of the $485 \mathrm{~nm}$ were plotted against molar fractions of 1 and $\mathrm{Pb}^{2+}$ under a condition of the constant total concentration. As such, the concentration of $1-\mathrm{Pb}^{2+}$ reached a turning point when the molar fraction of [1]/ $\left(\left[\mathrm{Pb}^{2+}\right]+[1]\right)$ was about 0.5 (see insert of Fig. 2). Accordingly, the association constant $K_{\mathrm{a}}$ was deduced to be as large as $(7.0 \pm 0.3) \times 10^{5} \mathrm{M}^{-1}$.

The key-role of crab chela made by the $\mathrm{py}_{2} \mathrm{pz}$ segment can be envisaged by the synthesis of complex 2 , in which the pyridyl lariate was replaced by the essentially inert phenyl group. As a result, negligible spectral changes were observed during the $\mathrm{Pb}^{2+}$ titration for complex 2 up addition to $10^{-3} \mathrm{M}$, providing a preliminary spectral evidence for the high activity of $\mathrm{py}_{2} \mathrm{pz}$ functional group in $\mathbf{1}$. Moreover, the definitive support for the $1-\mathrm{Pb}^{2+}$ structure is rendered by the single crystal X-ray structural analyses, for which the single crystals of $\mathbf{1}-\mathrm{Pb}^{2+}$ adduct were obtained from a slow diffusion of $\mathrm{Et}_{2} \mathrm{O}$ into a concentrated acetonitrile solution of a $1: 1$ mixture of 1 and $\mathrm{Pb}\left(\mathrm{ClO}_{4}\right)_{2}$. Its ORTEP diagram was depicted in Fig. 3, showing the typical pseudo-octrahedral coordination arrangement around the $\operatorname{Ir}(\mathrm{III})$ center. Similar to those of related cyclometalated $\operatorname{Ir}(\mathrm{III})$ complexes [21], the nitrogen atoms of the pdpz

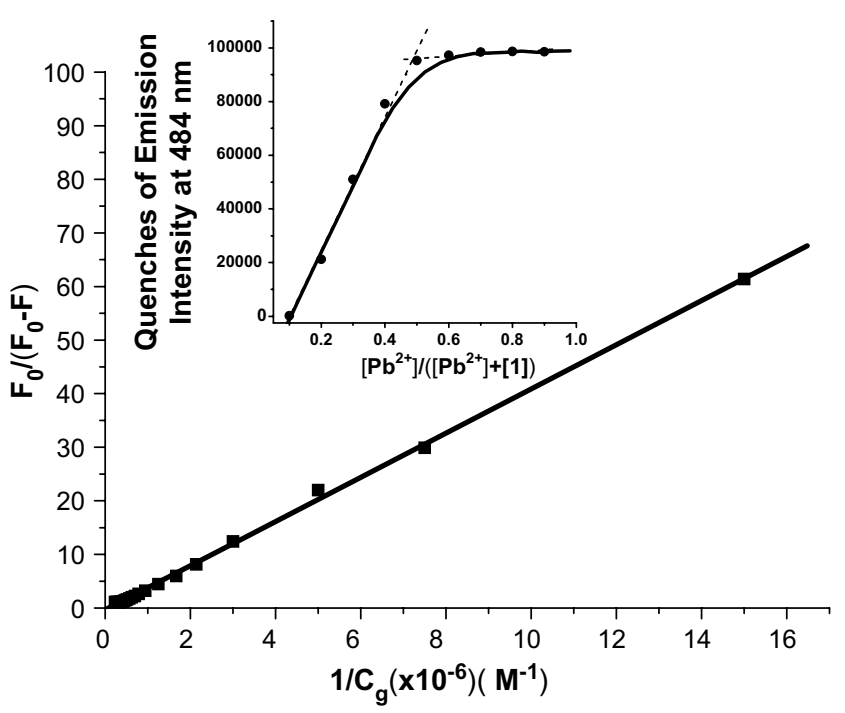

Fig. 2. The plot of $F_{0} / F_{0}-F$ against $1 / C_{\mathrm{g}}$ at $486 \mathrm{~nm}$. Insert: Job's plot of a 1:1 complex of 1 and $\mathrm{Pb}^{2+}$ cation, where the quenches of emission intensity at $484 \mathrm{~nm}$ was plotted against the mole fraction of $\mathrm{Pb}^{2+}$.

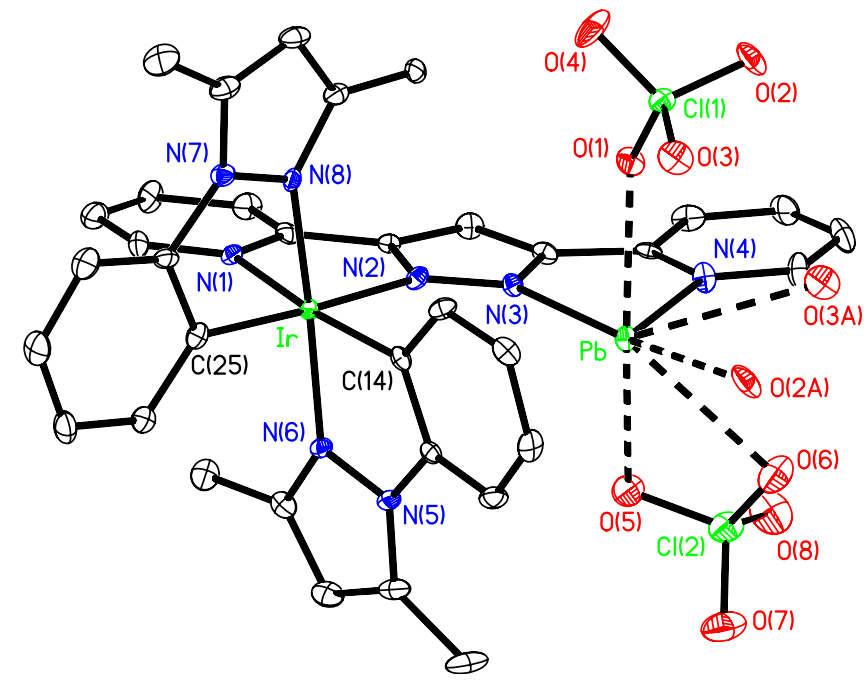

Fig. 3. ORTEP diagram of $1-\mathrm{Pb}^{2+}$ with thermal ellipsoids shown at $50 \%$ probability level; $\quad \operatorname{Ir}-\mathrm{N}(6)=2.023(5) \quad \operatorname{Ir}-\mathrm{N}(8)=2.028(5), \quad \operatorname{Ir}-\mathrm{N}(1)=$ $2.167(6), \quad \operatorname{Ir}-\mathrm{N}(2)=2.082(5), \quad \operatorname{Ir}-\mathrm{C}(25)=1.997(7), \quad \operatorname{Ir}-\mathrm{C}(14)=2.002(7)$, $\mathrm{Pb}-\mathrm{N}(3)=2.415(6), \mathrm{Pb}-\mathrm{N}(4)=2.471(5) \AA$.

ligands resided at the mutual trans-disposition, while the coordinated $\mathrm{N}$ atoms of $\mathrm{py}_{2} \mathrm{pz}$ ligands occupied the positions trans to the phenyl group of the pdpz ligands. All the $\mathrm{Ir}-\mathrm{C}$ and $\mathrm{Ir}-\mathrm{N}$ bond distances are unremarkable, as they falled in the range typical for these heteroleptic $\operatorname{Ir}(\mathrm{III})$ complexes reported in literatures. On the other hand, it is notable that the $\mathrm{Pb}^{2+}$ ion is linked to the outer pocket of $\mathrm{py}_{2} \mathrm{pz}$ ligand with $\mathrm{Pb}-\mathrm{N}$ distances being 2.415(6) and 2.471(5) $\AA$, which fall within the literature value [22]. Such a bridged $\mathrm{py}_{2} \mathrm{pz}$ bonding is akin to those of homodinuclear $\mathrm{py}_{2}$ pz complexes [23] and hybid complex containing lanthanide and transition metal elements such as $\left[(\mathrm{hfac})_{3} \mathrm{Ln}\right.$ $\left.\left(\mathrm{py}_{2} \mathrm{pz}\right) \mathrm{Cr}(\mathrm{acac})_{2}\right]$ [24].

Competitive experiments have been performed using the same titration method for other metal cations, including alkali, alkaline earth metals and certain heavy metals. While there is apparently no spectral changes for alkali metal ions, the associated absorption spectra revealed a small amount of changes for alkaline and $\mathrm{Hg}^{2+}$ ions (see Figs. 4 and 5 for $\mathrm{Ca}^{2+}$ and $\mathrm{Hg}^{2+}$ titration). However, except for $\mathrm{Hg}^{2+}$, none of them revealed appreciable changes in terms of emission profile and intensity in the range of $10^{-6}-10^{-3} \mathrm{M}$ (also see Fig. 6). Addition of $\mathrm{Hg}^{2+}$ exhibited an emission quenching effect but with a smaller $K_{\mathrm{a}}$. Based on a similar approach with that used for the $\mathrm{Pb}^{2+}$ titration, the association constant was determined to be $(5.9 \pm 0.3) \times$ $10^{4} \mathrm{M}^{-1}$ and $(1.0 \pm 0.2) \times 10^{4} \mathrm{M}^{-1}$ for $\mathrm{Hg}^{2+}$ and $\mathrm{Ca}^{2+}$ (absorption titration), respectively. The association constant for those selected metal ions are all less than that for $\mathrm{Pb}^{2+}$ by more than one order of the magnitude. This can also be illustrated by the phosphorescence intensity ratio of $1\left(2 \times 10^{-5} \mathrm{M}\right.$ in acetonitrile $)$ in the presence of selected metal ion $\left(10^{-3} \mathrm{M}\right)$ before and after adding $10^{-3} \mathrm{M}$ of $\mathrm{Pb}^{2+}$ shown in Fig. 6. The highly selective effect can be qualitatively rationalized by the amount of charge 


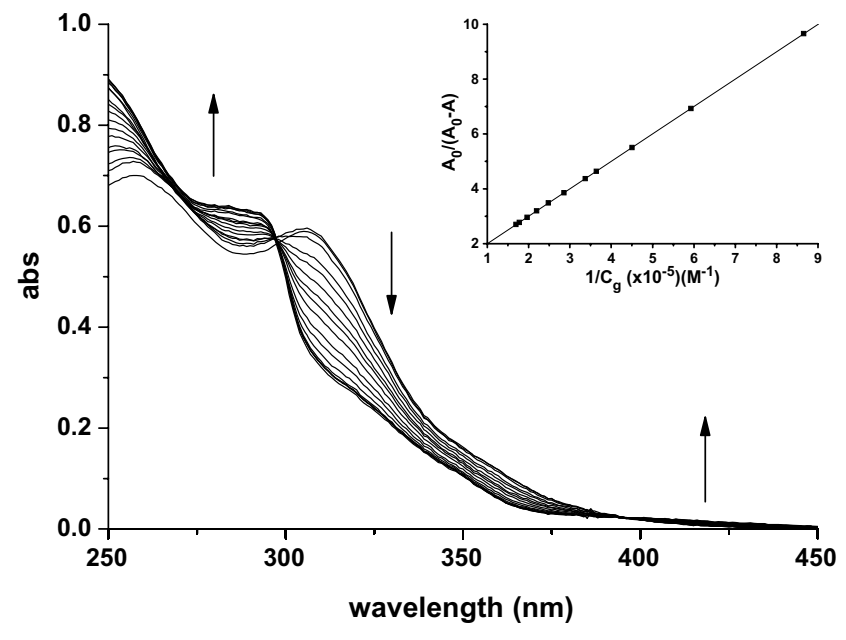

Fig. 4. The absorption spectra of $\mathbf{1}\left(2.0 \times 10^{-5}\right.$ in aerated $\left.\mathrm{CH}_{3} \mathrm{CN}\right)$ upon addition of increasing amounts of $\mathrm{Ca}^{2+}$ at (a) 0 , (b) $1.16 \times 10^{-5}$, (c) $1.69 \times 10^{-5}, \quad$ (d) $2.22 \times 10^{-5}$, (e) $2.75 \times 10^{-5}, \quad$ (f) $2.97 \times 10^{-5}, \quad$ (g) $3.50 \times 10^{-5}, \quad$ (h) $4.03 \times 10^{-5}, \quad$ (i) $4.56 \times 10^{-5}, \quad$ (j) $5.09 \times 10^{-5}, \quad$ (k) $5.63 \times 10^{-5}$, (1) $5.89 \times 10^{-5} \mathrm{M}$ of $\mathbf{1}$. Insert: the plot of $A_{0} /\left(A_{0}-A\right)$ against $1 / C_{\mathrm{g}}$ at $306 \mathrm{~nm}$.

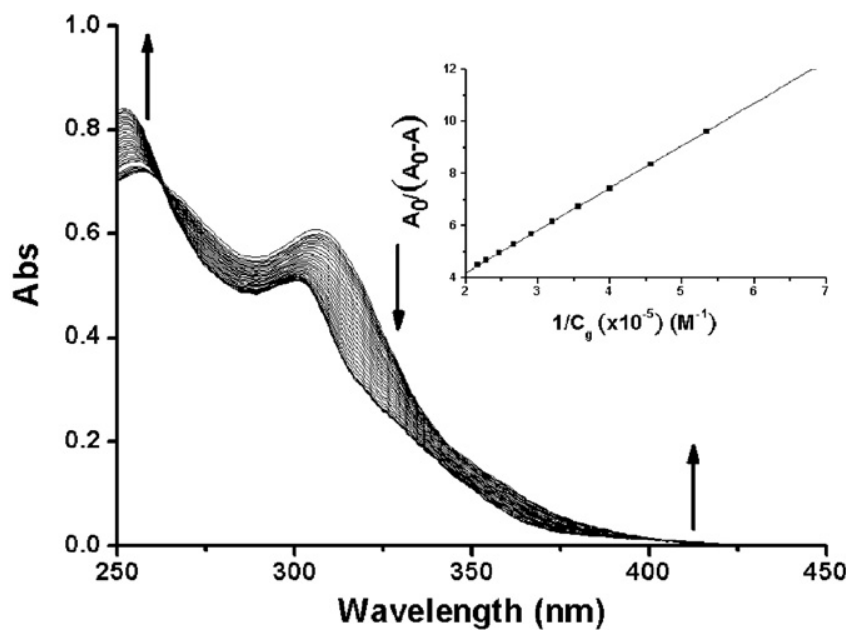

Fig. 5. The absorption spectra of $\mathbf{1}\left(2.0 \times 10^{-5}\right.$ in aerated $\left.\mathrm{CH}_{3} \mathrm{CN}\right)$ upon addition of increasing amounts of $\mathrm{Hg}^{2+}$ at (a) 0 , (b) 0.31 , (c) 0.63 , (d) 0.94 , (e) 1.25 , (f) 1.47, (g) 1.88 , (h) 2.19 , (i) 2.50 , (j) 2.81 , (k) 3.13 , (l) 3.44, (m) 3.75, (n) 4.06, (o) 4.38, (p) 4.61, (q) 5.00, (r) 5.31, (s) 5.63 (t) 5.94, (u) 6.25, (v) 6.56, (w) 6.87, (x) 7.19, (y) 7.50, (z) 7.81, (aa) 8.13, (ab) 8.44, (ac) 8.75, (ad) 9.06 , (ae) $9.38 \mu \mathrm{M}$ of 1 . Insert: the plot of $A_{0} /\left(A_{0}-A\right)$ against $1 / C_{\mathrm{g}}$ at $306 \mathrm{~nm}$.

density, $\rho$, specified as $\rho=g /\left(4 / 3 \pi r^{3}\right)$ where $\mathrm{g}$ and $\mathrm{r}$ are the corresponding formal charge $(+1$ or +2$)$ and radius, respectively. For example, the reciprocal of $r^{3}$ (the Shannon effective ionic radius with coordination number of 8 : $\mathrm{Pb}^{2+} \sim 1.29, \mathrm{Hg}^{2+} \sim 1.16$, and $\mathrm{Ca}^{2+} \sim 1.12$ ) [25] correlates well with the trend of the association constants.

We have also examined whether a similar recognition capability can be applied in the heterogeneous solid film in aqueous solution. Since $\mathbf{1}$ is insoluble in water, to simplify the process, a silica-based TLC plate was used as a solid support to soak $\mathbf{1}$ in $\mathrm{CH}_{3} \mathrm{CN}$ so that a complex $\mathbf{1}$ coated TLC plate was prepared with an optical density of

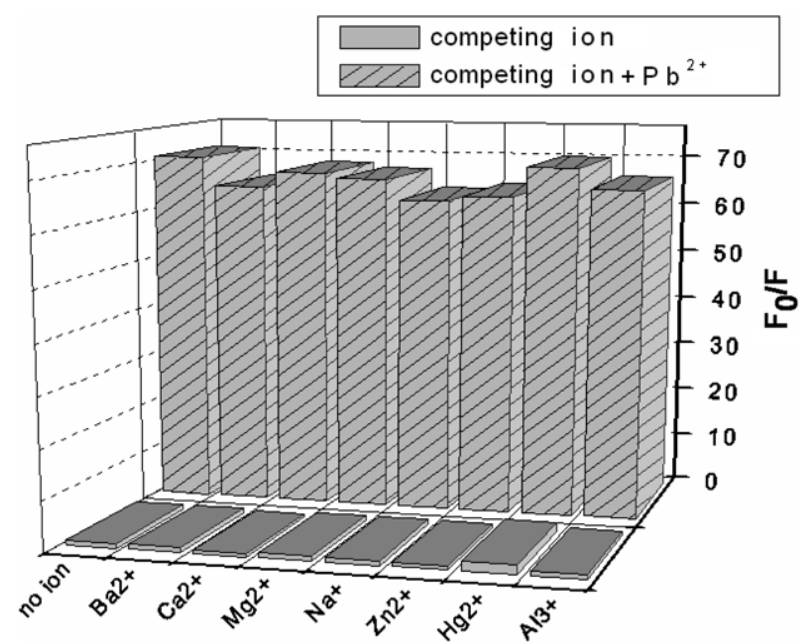

Fig. 6. (Grey) The phosphorescence intensity ratio of ion-free $\mathbf{1}\left(F_{0}\right.$, $2 \times 10^{-5} \mathrm{M}$ in acetonitrile) versus $\mathbf{1}$ in the presence of the selected metal ions $\left(10^{-3} \mathrm{M}\right)$. The phosphorescence intensity ratio of ion-free $\mathbf{1}$ vs. 1 in the presence of the selected metal ions $\left(10^{-3} \mathrm{M}\right)$, followed by addition of $10^{-3} \mathrm{M}$ of $\mathrm{Pb}^{2+}$ ion (Slash-Grey).

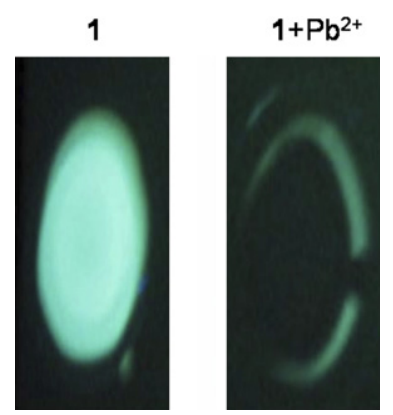

Fig. 7. The color of the sensor developed on a TLC plate with 1 in $\mathrm{CH}_{3} \mathrm{CN}$ (left) and with $\mathrm{Pb}^{2+}$ solution in $\mathrm{H}_{2} \mathrm{O}$ (right) was illuminated under $365 \mathrm{~nm}$ (UV lamp) for visualization (see text for the experimental detail). (For interpretation of the references to colour in this figure legend, the reader is referred to the web version of this article.)

$\sim 1.0$ at $350 \mathrm{~nm}$. Then we transfer a drop $(\sim 10 \mu \mathrm{L})$ of an aqueous solution $\left(\mathrm{pH} \sim 7.0\right.$ ) containing $\sim 10^{-4} \mathrm{M}$ of $\mathrm{Pb}\left(\mathrm{ClO}_{4}\right)_{2}$ solution onto the plate, and then vacuum-dried to remove water. With the use of a commercially available UV-lamp $(365 \mathrm{~nm})$, photograph demonstrates a salient change of emission from blue-green (complex 1) to a nearly dark state upon complexation with $\mathrm{Pb}^{2+}$ ion (see Fig. 7), implying the feasibility of $\mathbf{1}$ in sensing $\mathrm{Pb}^{2+}$ in aqueous solution down to nanomolar scales.

\section{Conclusions}

In conclusion, we apply complex 1 to demonstrate the concept of sensing $\mathrm{Pb}^{2+}$ ion based on the rare metal-ion sensitive phosphorescence. The ligated chromophores act as both recognition and signal-transmitting units, while the heavy metal, i.e. both $\operatorname{Ir}(\mathrm{III})$ ion and guest $\mathrm{Pb}^{2+}$, serve as perturbing bases to enhance and quench 
the phosphorescence, respectively. The emission quenching effect must be due to the affected core chromophores, i.e., the di(2-pyridyl) pyrazolate, that directly linked with $\mathrm{Pb}^{2+}$, provoking the intersystem crossing to another lower-lying triplet state for the host molecule via an enhanced spin-orbit coupling. Consequently, the emission intensity will plausibly be quenched due to a smaller $T_{1-}$ $\mathrm{S}_{0}$ energy gap.

On the other hand, the internal motion of the uncoordinated pyridyl substituent can play some crucial role in the emission quenching mechanism. To obtain an enhanced emission, in future, one can design a host molecule which will increase its rigidity after the complexation without affecting its chromophore. In this approach, the current system is versatile in that the functionalization can be achieved with methods similar to that have been strategically designed for the ${ }^{1} \pi \pi^{*}$ (i.e. fluorescence) chromophores. In view of oxygen quenching, in a steady state approach, one can then saturate the solution with $\mathrm{N}_{2}$ so that the enhanced phosphorescence can also serve as an additional signaling to distinguish it from the fluorescence interference. The success in the recognition of $\mathrm{Pb}^{2+}(\mathrm{aq})$ in the TLC plate demonstrates its suitability for the conceptual development of a practical recognization device. The results may spark a broad range of interest in both fundamental approach and applications relevant to third-row transition metal complexes.

\section{Acknowledgements}

We thank the National Science Council of Taiwan, ROC for the financial Support.

\section{Appendix A. Supplementary material}

CCDC 643498 contains the supplementary crystallographic data for $1-\mathrm{Pb}^{2+}$. These data can be obtained free of charge via http://www.ccdc.cam.ac.uk/conts/retrieving. html, or from the Cambridge Crystallographic Data Centre, 12 Union Road, Cambridge CB2 1EZ, UK; fax: $(+44)$ 1223-336-033; or e-mail: deposit@ccdc.cam.ac.uk. Supplementary data associated with this article can be found, in the online version, at doi:10.1016/j.poly.2007.06.029.

\section{References}

[1] C.-T. Chen, W.-P. Huang, J. Am. Chem. Soc. 124 (2002) 6246.

[2] http://www.epa.gov/safewater/mcl.html.

[3] (a) V. Amendola, L. Fabbrizzi, M. Lincchelli, C. Mangano, P. Pallavicini, L. Parodi, A. Poggi, Coord. Chem. Chem. Rev. 190-192 (1999) 649;

(b) J. Liu, Y. Lu, J. Am. Chem. Soc. 125 (2003) 6642;

(c) J. Li, Y. Lu, J. Am. Chem. Soc. 122 (2000) 10466;

(d) M. Sun, D. Shangguan, H. Ma, L. Nie, X. Li, S. Xiong, G. Liu, W. Thiemann, Biopolymers 72 (2003) 413;

(e) F.-Y. Wu, S.W. Bae, J.-I. Hong, Terahedron Lett. 47 (2006) 8851 ;

(f) M. Kadarkaraisamy, G.A. Sykes, Inorg. Chem. 45 (2006) 779 ; (g) D.P. Wernette, C.B. Swearingen, D.M. Cropek, M. Donald, Y. Lu, J.V. Sweedler, P.W. Bohn, Analyst 131 (2006) 41.

[4] S. Deo, H.A. Godwin, J. Am. Chem. Soc. 122 (2000) 174.

[5] M.-Y. Chae, J. Yoon, A.W. Czarnik, J. Mol. Recognit. 9 (1996) 297.

[6] J.Y. Kwon, Y.J. Jang, Y.J. Lee, K.M. Kim, M.S. Seo, W. Nam, J. Yoon, J. Am. Chem. Soc. 127 (2005) 10107.

[7] (a) R. Slone, D.I. Yoon, R.M. Calhoun, J.T. Hupp, J. Am. Chem. Soc. 117 (1995) 11813;

(b) P.K.M. Siu, S.-W. Lai, W. Lu, N. Zhu, C.-M. Che, Eur. J. Inorg. Chem. (2003) 2749;

(c) Q.-Z. Yang, L.-Z. Wu, H. Zhang, B. Chen, Z.-X. Wu, L.-P. Zhang, C.-H. Tung, Inorg. Chem. 43 (2004) 5195;

(d) M.-J. Li, B.W.-K. Chu, N. Zhu, V.W.-W. Yam, Inorg. Chem. 46 (2007) 720 .

[8] (a) Y. Shen, B.P. Sullivan, Inorg. Chem. 34 (1995) 6235;

(b) V.W.-W. Yam, C.-L. Chan, C.-K. Li, K.M.-C. Wong, Coord. Chem. Rev. 216-217 (2001) 173;

(c) V.W.-W. Yam, R.P.-L. Tang, K.M.-C. Wong, X.-X. Lu, K.-K. Cheung, N. Zhu, Chem. Eur. J. 8 (2002) 4066;

(d) L.J. Charbonniere, R.F. Ziessel, C.A. Sams, A. Harriman, Inorg. Chem. 42 (2003) 3466

[9] (a) J. Ohshita, T. Uemura, T. Inoue, K. Hino, A. Kunai, Organometallics 25 (2006) 2225;

(b) S.A. McFarland, D. Magde, N.S. Finney, Inorg. Chem. 44 (2005) 4066;

(c) M.-J. Li, B.W.-K. Chu, V.W.-W. Yam, Chem. Eur. J. 12 (2006) 3528.

[10] (a) J.F. Michalec, S.A. Bejune, D.G. Cuttell, G.C. Summerton, J.A. Gertenbach, J.S. Field, R.J. Haines, D.R. McMillin, Inorg. Chem. 40 (2001) 2193;

(b) J.D. Lewis, L. Bussotti, P. Foggi, R.N. Perutz, J.N. Moore, J. Phys. Chem. A 106 (2002) 12202;

(c) J.D. Lewis, J.N. Moore, Dalton Trans. (2004) 1376;

(d) W.-S. Tang, X.-X. Lu, K.M.-C. Wong, V.W.-W. Yam, J. Mater. Chem. 15 (2005) 2714.

[11] M.-L. Ho, F.-M. Hwang, P.-N. Chen, Y.-H. Hu, Y.-M. Cheng, K.-S. Chen, G.-H. Lee, Y. Chi, P.-T. Chou, Org. Biomol. Chem. (2006) 98.

[12] D.S. McClure, J. Chem. Phys. 20 (1952) 682.

[13] (a) P.-T. Chou, Y. Chi, Chem. Eur. J. 13 (2007) 380; (b) P.-T. Chou, Y. Chi, Eur. J. Inorg. Chem. (2006) 3319.

[14] (a) C.-H. Yang, S.-W. Li, Y. Chi, Y.-M. Cheng, Y.-S. Yeh, P.-T. Chou, G.-H. Lee, C.-H. Wang, C.-F. Shu, Inorg. Chem. 44 (2005) 7770 ;

(b) C.-J. Chang, C.-H. Yang, K. Chen, Y. Chi, C.-F. Shu, M.-L. Ho, Y.-S. Yeh, P.-T. Chou, Dalton Trans. (2007) 1881.

[15] (a) Y. Shen, B.P. Sullivan, J. Chem. Edu. 74 (1997) 685; (b) P.D. Beer, S.W. Dent, N.C. Fletcher, T.J. Wear, Polyhedron 15 (1996) 2983;

(c) M.E. Padilla-Tosta, J.M. Lloris, R. Martinez-Manez, M.D. Marcos, M.A. Miranda, T. Pardo, F. Sancenon, J. Soto, Eur. J. Inorg. Chem. (2001) 1475.

[16] T. Lazarides, T.A. Miller, J.C. Jeffery, T.K. Ronson, H. Adams, M.D. Ward, Dalton Trans. (2005) 528.

[17] W.-S. Yu, C.-C. Cheng, Y.-M. Cheng, P.-C. Wu, Y.-H. Song, Y. Chi, P.-T. Chou, J. Am. Chem. Soc. 125 (2003) 10800.

[18] (a) P.-T. Chou, G.-R. Wu, C.-Y. Wei, C.-C. Cheng, C.-P. Chang, F.-T. Hung, J. Phys. Chem. B 103 (1999) 10042;

(b) P.-T. Chou, G.-R. Wu, C.-Y. Wei, C.-C. Cheng, C.-P. Chang, F.-T. Hung, J. Phys. Chem. B 104 (2000) 7818;

(c) P.-T. Chou, C.-Y. Wei, C.-R.C. Wang, F.-T. Hung, C.-P. Chang, J. Phys. Chem. A 103 (1999) 1939.

[19] C.Y. Chen, C.T. Cheng, J.K. Yu, S.C. Pu, Y.M. Cheng, P.T. Chou, Y.H. Chou, H.T. Chiu, J. Phys. Chem. B 108 (2004) 10687.

[20] K.A. Connors, Binding Constants, Wiley, New York, 1987.

[21] (a) Y.-H. Song, S.-J. Yeh, C.-T. Chen, Y. Chi, C.-S. Liu, J.-K. Yu, Y.-H. Hu, P.-T. Chou, S.-M. Peng, G.-H. Lee, Adv. Funct. Mater. 14 (2004) 1221; 
(b) F.-M. Hwang, H.-Y. Chen, P.-S. Chen, C.-S. Liu, Y. Chi, C.-F. Shu, F.-I. Wu, P.-T. Chou, S.-M. Peng, G.-H. Lee, Inorg. Chem. 44 (2005) 1344;

(c) C.-H. Yang, Y.-M. Cheng, Y. Chi, C.-J. Hsu, F.-C. Fang, K.-T. Wong, P.-T. Chou, C.-H. Chang, M.-H. Tsai, C.-C. Wu, Angew. Chem., Int. Ed. 46 (2007) 2418.

[22] E. Psillakis, J.C. Jeffery, J.A. McCleverty, M.D. Ward, Chem. Commun. (1997) 1965.
[23] J. Casabo, J. Pons, K.S. Siddiqi, F. Teixidor, E. Molins, C. Miravitlles, J. Chem. Soc., Dalton Trans. (1989) 1401.

[24] R. Kawahata, T. Tsukuda, T. Yagi, M.A. Subhan, H. Nakata, A. Fuyuhiro, S. Kaizaki, Chem. Lett. 32 (2003) 1084.

[25] Q.-Z. Yang, Q.-X. Tong, L.-Z. Wu, Z.X. Wu, L.P. Zhang, C.H. Tung, Eur. J. Inorg. Chem. (2004) 1948. 